\title{
Synthesis and Molten-State Polymerization of Some Novel Conjugated Diacetylenes
}

\author{
Lioudmila Fomina, Hector Allier, Sergei Fomine, \\ Roberto SAlCEDo, and Takeshi OGaWA* \\ Instituto de Investigaciones en Materiales, Circuito Exterior, \\ Ciudad Universitaria, México DF 04510, Mexico
}

(Received November 24, 1994)

\begin{abstract}
A series of new, highly conjugated diacetylenes, 4-ethynylstilbene derivatives, were synthesized and their polymerization was studied. None of them was found to undergo topochemical polymerization in the solid state but they readily polymerized in the molten state to give red transparent and amorphous polymers. All the polymers had an absorption maximum in the visible spectra around $500 \mathrm{~nm}$, and FT-IR data showed the enyne structure of the polymer chain resulted from 1,4 -addition.

KEY WORDS Diacetylene / Amorphous Polydiacetylenes / Wittig Reaction / Aromatic Acetylenes /
\end{abstract}

Since Wegner ${ }^{1}$ first reported the topochemical polymerization of diacetylenes (DA) much has been published, ${ }^{2}$ and considerable attention has been paid to the crystalline polydiacetylenes (PDA) because of their possible applications in nonlinear optical (NLO) devices. ${ }^{3}$ It is generally accepted that the processing of PDAs is not as easy as that of most polymers. Various methods are available for obtaining films of PDAs. ${ }^{4}$ Many PDAs are poorly soluble in most organic solvents, and the casting of films from their solutions often gives films with poor transparency. The Langmuir-Blodgett technique is an interesting and useful method to obtain ultra thin films of amphiphylic DAs, but there are still problems to be solved in preparing films of sufficient thickness for application in devices. The vacuum evaporationepitaxy method may be employed for a limited number of DAs. The majority of DAs, with a few exceptions ${ }^{5}$ do not give single crystals large enough for applications. Moreover, it must be remembered that not all DAs undergo topochemical polymerization, and therefore the above mentioned methods are limited to a relatively small number of DAs, which have so far been thoroughly studied.

From the point of view of easy processing, DA-containing processable polymers are interesting materials because films or fibers of any desired dimension can be readily obtained. ${ }^{6}$ PDA microcrystals dispersed in a transparent host polymer is another possible route to achieve high optical quality materials for NLO applications. ${ }^{7}$

Totally amorphous PDAs are another class of materials having highly conjugated structures, which can be obtained by the polymerization of DAs in the molten state. The third order NLO susceptibilites $\left(\chi^{(3)}\right)$ of these amorphous PDAs might not be as high as those which the crystalline PDAs are expected to have, but they have advantages over the conventional crystalline PDAs, in that they are extremely transparent and can be made into any shape required for application, such as thin films sandwiched between quartz windows, sheets, blocks, fibers, etc. Another advantage of the amorphous polymerization process is that aromatic DAs can be employed and there-

\footnotetext{
* To whom correspondence should be addressed.
} 
fore increased conjugation systems can be obtained. The present authors have reported previously that highly transparent red films are obtained by the thermal polymerization and $\gamma$-ray irradiation in the molten state of aromatic DAs. ${ }^{8-10}$ Preliminary determination of $\chi^{(3)}$ of these amorphous materials are of the order of $10^{-10} \mathrm{esu}$. It is worth mentioning that not all DAs undergo amorphous polymerization under controlled conditions. Many topochemically polymerizable DAs do not polymerize in the amorphous state.

In this work several novel aromatic DAs were synthesized, and their polymerization in the molten state was studied. The results are reported in this paper.

\section{EXPERIMENTAL}

\section{Materials}

Methylene chloride used for the Wittig reaction, was distilled over $\mathrm{CaH}_{2}$. Other reagents were used as received (Aldrich).

\section{Monomer Synthesis}

(Trimethylsilylethynyl)benzaldehyde (2) and 4-ethynylbenzaldehyde (4) were prepared according to the method described in the literature. ${ }^{11}$ The synthesis of the monomers is shown in Scheme 1.

$\beta, \beta$-Dibromo-4-[(trimethylsilyl)ethynyl $]-$ styrene (3). Carbon tetrabromide $(20.0 \mathrm{mmol})$ was dissolved in $150 \mathrm{ml}$ of $\mathrm{CH}_{2} \mathrm{Cl}_{2}$ and triphenylphosphine (TPP) $(38.3 \mathrm{mmol})$ was added under nitrogen to the solution with stirring. After 10 min 4-(Trimethylsilylethynyl)benzaldehyde (2) (22 mmol) was added to the solution at room temperature and the reaction was monitored by thin layer chromatography (TLC). After 1 hour the solvent was evaporated under vacuum, and the residue was extracted twice with $200 \mathrm{ml}$ of hot hexane. The extract was concentrated to $100 \mathrm{ml}$ and chromatographed on $\mathrm{SiO}_{2}$ with hexane to give a $70 \%$ yield of compound $3 . T_{\mathrm{m}}=65^{\circ} \mathrm{C}$. FT-IR $\left(\mathrm{cm}^{-1}\right)$ 3030-3010 (C-H ar.), 2950 (C-H al.), 2152
$(-\mathrm{C} \equiv \mathrm{C}-), 1591(\mathrm{C}=\mathrm{C}$ ar. $), 1248(\mathrm{Si}-\mathrm{C}), 698$ $(\mathrm{C}-\mathrm{Br}) .{ }^{1} \mathrm{H}$ NMR in $\mathrm{CDCl}_{3}(\delta) 0.20(\mathrm{~s}, 9 \mathrm{H}$, $\left.\left(\mathrm{CH}_{3}\right)_{3}-\mathrm{Si}-\right), 7.16-7.32(\mathrm{~m}, 5 \mathrm{H}$, ar.).

$\beta, \beta$-Di(ethynylphenyl)-4-((trimethylsilyl)ethynyl)styrene (5). Compound $3(15 \mathrm{mmol})$, phenylacetylene $(40 \mathrm{mmol})$ TPP $(0.2 \mathrm{~g}), \mathrm{CuI}$ $(0.1 \mathrm{~g})$ and triethylamine (TEA) $(150 \mathrm{ml})$ were refluxed for 2 hours under nitrogen. TEA was evaporated under vacuum and the residue was chromatographed on $\mathrm{SiO}_{2}$ with a mixture of hexane-benzene $(10: 1)$. Yield $75 \%, T_{\mathrm{m}}=84^{\circ} \mathrm{C}$. FT-IR ( $\left.\mathrm{cm}^{-1}\right) \quad 3080-3010$ (C-H ar.), 2950 (C-H al.), 2201 ( $-\mathrm{C} \equiv \mathrm{C}-), 2152$ ( $-\mathrm{C} \equiv \mathrm{C}-\mathrm{Si})$, 1595 ( $\mathrm{C}=\mathrm{C}$ ar.), 1248 ( $\mathrm{Si}-\mathrm{C}) .{ }^{1} \mathrm{H}$ NMR in $\mathrm{CDCl}_{3}(\delta) 0.20\left(\mathrm{~s}, 9 \mathrm{H},\left(\mathrm{CH}_{3}\right)_{3}-\mathrm{Si}-\right), 7.10(\mathrm{~s}$, $1 \mathrm{H},\left(-\mathrm{CH}=\mathrm{C}(\mathrm{C} \equiv \mathrm{CPh})_{2}\right), 7.16-7.70(\mathrm{~m}, 10 \mathrm{H}$ ar.), $7.70-8.00$ (d, $4 \mathrm{H}$ ar.).

$\beta, \beta$-Di(ethynylphenyl)-4-ethynylstyrene (6). A solution of $11 \mathrm{mmol}$ of compound 5 and $0.2 \mathrm{~g}$ of $\mathrm{KOH}$ was stirred for 4 hours at room temperature then $\mathrm{KOH}$ was neutralized by dilute $\mathrm{HCl}$ and methanol was removed under vacuum. The residue was chromatographed on $\mathrm{SiO}_{2}$ with a hexane-benzene mixture (10:1). Yield $85 \% . T_{\mathrm{m}}=120-122^{\circ} \mathrm{C}$. FT-IR $\left(\mathrm{cm}^{-1}\right)$ $3292(\mathrm{C} \equiv \mathrm{C}-\mathrm{H}), 3080-3010$ (C-H ar.), 2187 $(-\mathrm{C} \equiv \mathrm{C}-), 2100(-\mathrm{C} \equiv \mathrm{CH}), 1600(\mathrm{C}=\mathrm{C}$ ar. $)$, ${ }^{1} \mathrm{H}$ NMR in $\mathrm{CDCl}_{3}(\delta): 3.10(\mathrm{~s}, 1 \mathrm{H}, \mathrm{HC} \equiv \mathrm{C}-)$, $7.10\left(\mathrm{~s}, 1 \mathrm{H},\left(-\mathrm{CH}=\mathrm{C}(\mathrm{C} \equiv \mathrm{CPh})_{2}\right), 7.16-7.70\right.$ (m, 10H ar.), 7.70-8.00 (d, 4H ar.).

(E)-4-ethynyl-4'-n-butoxystylbene (7a) and (Z)-4-ethynyl-4'-n-butoxystylbene (8a). 9.89 mmol of (4- $n$-butoxy)benzyltriphenylphosphonium bromide were dispersed in $150 \mathrm{ml}$ of dry toluene under nitrogen and $5 \mathrm{ml}$ of a $2.5 \mathrm{M}$ solution of $n$-BuLi in hexane $(13 \mathrm{mmol})$ were added at room temperature with stirring. The red solution was stirred for 2 hours and then $12 \mathrm{mmol}$ of 4-ethynylbenzaldehyde (4) were added and the reaction mixture was stirred for 4 hours. Then the solution was washed with water, dried over $\mathrm{Na}_{2} \mathrm{SO}_{4}$ and toluene was evaporated under vacuum. The residue was extracted with hot hexane and filtered through $\mathrm{SiO}_{2}$ to give mixture of $7 \mathbf{a}$ and $8 \mathrm{a}$ in $84 \%$ yield. The mixture of isomers was dissolved in hot 
hexane and compound 7a precipitated on cooling. The compound was filtered off and the solution was evaporated under vacuum to give 8a as a light oil. 7a: $T_{\mathrm{m}}=177^{\circ} \mathrm{C}$, FT-IR $\left(\mathrm{cm}^{-1}\right)$ 3289 (C $\equiv \mathrm{C}-\mathrm{H}), 3080-3020$ (C-H ar.), 2105 $(-\mathrm{C} \equiv \mathrm{CH}), 1600(\mathrm{C}=\mathrm{C}$ ar. $), 1250\left(\mathrm{C}_{\mathrm{ar}}-\mathrm{O}\right), 1160$ $\left(\mathrm{C}_{\mathrm{ar}}-\mathrm{O}\right), 956$ (trans $-\mathrm{CH}=\mathrm{CH}-$ ), ${ }^{1} \mathrm{H} \mathrm{NMR}$ in $\mathrm{CDCl}_{3}(\delta): 0.95\left(\mathrm{t}, 3 \mathrm{H}, \mathrm{CH}_{3}-\right), 1.15-2.00(\mathrm{~m}$, $\left.4 \mathrm{H},-\mathrm{CH}_{2} \mathrm{CH}_{2}-\right), 3.10(\mathrm{~s}, 1 \mathrm{H}, \mathrm{HC} \equiv), 3.95(\mathrm{t}$, $\left.2 \mathrm{H}, \mathrm{CH}_{2} \mathrm{O}-\right), 6.70-7.50(\mathrm{~m}, 10 \mathrm{H}, 8 \mathrm{H}$ ar, trans$\mathrm{CH}=\mathrm{CH})$. 8a: FT-IR $\left(\mathrm{cm}^{-1}\right) 3289(\mathrm{C} \equiv \mathrm{C}-\mathrm{H})$, 3080-3020 (C-H ar.), 2950-2850 (C-H al.), $2105(-\mathrm{C} \equiv \mathrm{CH}), 1600(\mathrm{C}=\mathrm{C}$ ar. $), 1250\left(\mathrm{C}_{\mathrm{ar}}-\mathrm{O}\right)$, $1160\left(\mathrm{C}_{\mathrm{al}}-\mathrm{O}\right) .{ }^{1} \mathrm{H} \mathrm{NMR}$ in $\mathrm{CDCl}_{3}(\delta): 0.95(\mathrm{t}$, $\left.3 \mathrm{H}, \mathrm{CH}_{3}-\right), 1.15-2.00\left(\mathrm{~m}, 4 \mathrm{H},-\mathrm{CH}_{2} \mathrm{CH}_{2}-\right)$, $3.00(\mathrm{~s}, 1 \mathrm{H}, \mathrm{HC} \equiv), 3.85\left(\mathrm{t}, 2 \mathrm{H}, \mathrm{CH}_{2} \mathrm{O}-\right)$, $6.30-6.40(\mathrm{~m}, 2 \mathrm{H}$ cis- $\mathrm{CH}=\mathrm{CH}-), 6.50-7.50$ (m, 8H ar.).

(E)-4-ethynyl-4'-nitrostylbene (7b) and (Z)-4ethynyl-4'-nitrostylbene $(\mathbf{8 b})$. To a solution of (4-nitro)benzyltriphenylphosphonium bromide (33.3 $\mathrm{mmol})$ and compound $4(33.3 \mathrm{mmol})$ in $200 \mathrm{ml}$ of $\mathrm{MeOH}, 100 \mathrm{ml}$ of $\mathrm{MeOH}$ solution containing $\mathrm{KOH}$ (33.3 mmol) were added dropwise over 1 hour. The reaction mixture was then stirred for 1 hour, $\mathrm{MeOH}$ was evaporated under vacuum, and the residue was chromatographed on $\mathrm{SiO}_{2}$ with a benzene-hexane mixture $(10: 1)$ to give $1.9 \mathrm{~g}$ of $7 \mathrm{~b}$ and $3.5 \mathrm{~g}$ of 8b. 7b: $T_{\mathrm{m}}=186^{\circ} \mathrm{C}(\mathrm{dec})$. FT-IR $\left(\mathrm{cm}^{-1}\right) 3280$ $(\mathrm{C} \equiv \mathrm{C}-\mathrm{H}), 3080-3020$ (C-H ar.), $2100(-\mathrm{C} \equiv$ $\mathrm{CH}), 1593(\mathrm{C}=\mathrm{C}$ ar. $), 1512,1340\left(-\mathrm{NO}_{2}\right)$, 954 (trans $-\mathrm{CH}=\mathrm{CH}-$ ). ${ }^{1} \mathrm{H}$ NMR in $\mathrm{CDCl}_{3}(\delta)$ : $3.10(\mathrm{~s}, 1 \mathrm{H}, \mathrm{HC} \equiv), 7.20(\mathrm{~s}, 2 \mathrm{H}$ trans $-\mathrm{CH}=$ $\mathrm{CH}-$ ), 7.50-7.80 (m, 6H ar.), 8.15-8.35 (d, $2 \mathrm{H}$ ar.). 8b: $T_{\mathrm{m}}=93-95^{\circ} \mathrm{C}$. FT-IR $\left(\mathrm{cm}^{-1}\right) 3280$ $(\mathrm{C} \equiv \mathrm{C}-\mathrm{H}), 3080-3020$ (C-H ar.), $2100(-\mathrm{C} \equiv$ $\mathrm{CH}), 1600(\mathrm{C}=\mathrm{C}$ ar. $), 1512,1340\left(-\mathrm{NO}_{2}\right) \cdot{ }^{1} \mathrm{H}$ $\mathrm{NMR}$ in $\mathrm{CDCl}_{3}(\delta): 3.10(\mathrm{~s}, 1 \mathrm{H}, \mathrm{HC} \equiv), 6.60$ $6.85(\mathrm{~m}, 2 \mathrm{H}$ cis $-\mathrm{CH}=\mathrm{CH}-), 7.05-7.60(\mathrm{~m}, 6 \mathrm{H}$ ar.), $8.00-8.20$ (d, $2 \mathrm{H}$ ar.).

4-Bromo-3-butyn-1-ol (10). To a solution of $\mathrm{NaOBr}$ prepared by mixing a solution of $27 \mathrm{~g}$ of $\mathrm{NaOH}$ in $100 \mathrm{ml}$ of water and $8 \mathrm{ml}$ of $\mathrm{Br}_{2}$ at $0^{\circ} \mathrm{C}, 20 \mathrm{~g}$ of 3-butyn-1-ol (9) were added dropwise at $0^{\circ} \mathrm{C}$ and the reaction mixture was stirred for 2 hours at room temperature. Then the mixture was extracted with ether and the extract was dried with $\mathrm{Na}_{2} \mathrm{SO}_{4}$. Ether was evaporated under vacuum and the residue was distilled under reduced pressure. Yield $75 \%$. $T_{\mathrm{b}}=55-56^{\circ} \mathrm{C} / 1 \mathrm{mmHg}$. FT-IR $\left(\mathrm{cm}^{-1}\right) 3400$ $(-\mathrm{OH}), 2950-2850$ (C-H al.), $2220(\mathrm{C} \equiv \mathrm{CBr})$. ${ }^{1} \mathrm{H}$ NMR $(\delta) 2.30\left(\mathrm{t}, 2 \mathrm{H} \equiv \mathrm{C}-\mathrm{CH}_{2}-\right), 3.20(\mathrm{~s}$, $1 \mathrm{H}, \mathrm{HO}-), 3.50$ (t, 2H, O- $\left.\mathrm{CH}_{2}\right)$.

4,4'-Bis- $((Z)-\beta-((4-n-b u t o x y)$ phenyl $)$ vinyl $)-$ diphenyldiacetylene (11a) and $4,4^{\prime}-$ bis $-((Z)-\beta-(4-$ nitrophenyl)vinyl)diphenyldiacetylene (11b). $0.05 \mathrm{mmol}$ of compound $8 \mathbf{a}$ or $8 \mathbf{b}$ were dissolved in $50 \mathrm{ml}$ of 2-propanol and $0.01 \mathrm{~g}$ of $\mathrm{CuCl}$ and $1 \mathrm{ml}$ of $N, N, N^{\prime}, N^{\prime}$-tetramethylethylenediamine (TMDA) were added to the solution. Oxygen was bubbled through the solution for 5 hours. The reaction mixture was poured into water, the solid precipitated was filtered off washed with water and recrystallized from 2-propanol. 11a: Yield $88 \%, T_{\mathrm{m}}=119^{\circ} \mathrm{C}$, FTIR ( $\left.\mathrm{cm}^{-1}\right) 3050-3000$ (C-H ar.), 2950-2850 (C-H al.), 2205, 2145, 2130 (C $\equiv C-C \equiv C) 1600$ $(\mathrm{C}=\mathrm{C}$ ar. $), 1250\left(\mathrm{C}_{\mathrm{ar}}-\mathrm{O}\right), 1174\left(\mathrm{C}_{\mathrm{al}}-\mathrm{O}\right) .{ }^{1} \mathrm{H}$ NMR in $\mathrm{CDCl}_{3}(\delta): 0.95\left(\mathrm{t}, 6 \mathrm{H}, \mathrm{CH}_{3}-\right), 1.15-$ $2.00\left(\mathrm{~m}, 8 \mathrm{H},-\mathrm{CH}_{2} \mathrm{CH}_{2}-\right), 3.95\left(\mathrm{t}, 4 \mathrm{H}, \mathrm{CH}_{2} \mathrm{O}-\right)$, $6.40-6.50(\mathrm{~m}, 4 \mathrm{H}$ cis- $\mathrm{CH}=\mathrm{CH}-), 6.60-7.50$ (m, 16H ar.). 11b: Yield $77 \%, T_{\mathrm{m}}=172^{\circ} \mathrm{C}, \mathrm{FT}$ IR $\left(\mathrm{cm}^{-1}\right), 3100-3000$ (C-H ar.), 2210, 2145 $(\mathrm{C} \equiv \mathrm{C}-\mathrm{C} \equiv \mathrm{C}), 1600(\mathrm{C}=\mathrm{C}$ ar. $), 1510,1340$ $\left(-\mathrm{NO}_{2}\right) .{ }^{1} \mathrm{H}$ NMR in $\mathrm{CDCl}_{3}(\delta): 6.60-6.80$ (m, $4 \mathrm{H}$ cis $-\mathrm{CH}=\mathrm{CH}-), 7.05-7.60(\mathrm{~m}, 12 \mathrm{H}$ ar.), $7.95-8.15(\mathrm{~d}, 4 \mathrm{H}$ ar. $)$.

6-((E)-4-( $\beta$-((4-butoxy)phenyl)vinyl $)$ phenyl $)$ hexa-1,3-diyne-1-ol(12a). To a solution of THF $(50 \mathrm{ml})$ containing $7 \mathrm{a}(5 \mathrm{mmol}), \mathrm{CuCl}(0.01 \mathrm{~g})$, $n$-butylamine $(2 \mathrm{ml})$, water $(2 \mathrm{ml})$, and $0.5 \mathrm{~g}$ of $\mathrm{NH}_{2} \mathrm{OH} \cdot \mathrm{HCl}$, a solution of $11(7 \mathrm{mmol})$ in $100 \mathrm{ml}$ of ethanol was added dropwise over 2 hours with stirring. Then the solvents were evaporated under vacuum and the residue was chromatographed on $\mathrm{SiO}_{2}$ with benzene to give compound 12a in $53 \%$ yield. $T_{\mathrm{m}}=221^{\circ} \mathrm{C}$. FTIR $\left(\mathrm{cm}^{-1}\right) 3350(-\mathrm{OH}), 3050-3000$ (C-H ar.), 2240, $2155(\mathrm{C} \equiv \mathrm{C}-\mathrm{C} \equiv \mathrm{C}), 1600(\mathrm{C}=\mathrm{C}$ ar. $)$, $1251\left(\mathrm{C}_{\mathrm{ar}}-\mathrm{O}\right), 1176\left(\mathrm{C}_{\mathrm{al}}-\mathrm{O}\right), 954$ (trans $-\mathrm{CH}=$ 
L. Fomina et al.

$\mathrm{Br} \longrightarrow \mathrm{Si}(\mathrm{Me})_{3}$

1

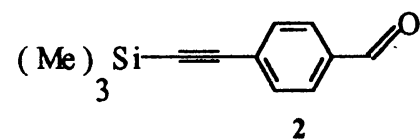

TP P $\mathrm{CBr}_{4}$

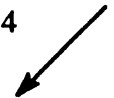<smiles>C[SiH2]C#Cc1ccc(C=C(Br)Br)cc1</smiles>

3<smiles>C#Cc1ccccc1</smiles><smiles>C[SiH2]C#Cc1ccc(C=C(C#Cc2ccccc2)C#CC(C)C)cc1</smiles><smiles>OCI</smiles>

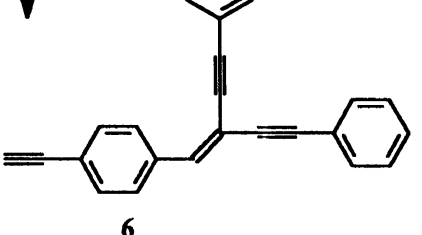

6

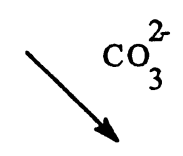<smiles>C#Cc1ccc(C=O)cc1</smiles>

4<smiles>Cc1ccc(C[P+](Br)(Br)Br)cc1</smiles>

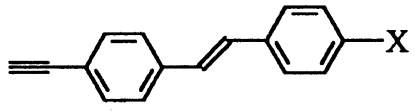

7 a $\mathrm{X}=\mathrm{OBu}$

7 b $\quad \mathrm{X}=\mathrm{NO}_{2}$

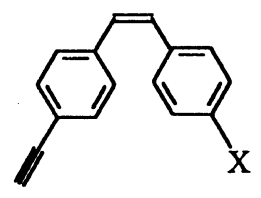

8 a $\mathrm{X}=\mathrm{OBu}$

8 b $\mathrm{X}=\mathrm{NO}_{2}$

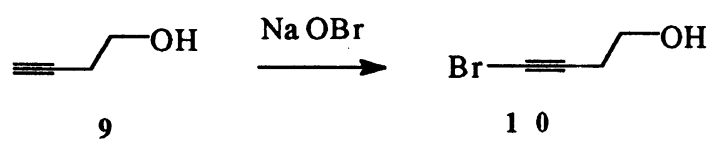

Scheme 1.

$\mathrm{CH}-) .{ }^{1} \mathrm{H}$ NMR in $\mathrm{CDCl}_{3}(\delta): 0.95(\mathrm{t}, 3 \mathrm{H}, \quad$ trans $-\mathrm{CH}=\mathrm{CH}-)$.

$\left.\mathrm{CH}_{3}-\right), 1.15-2.00\left(\mathrm{~m}, 5 \mathrm{H},-\mathrm{CH}_{2} \mathrm{CH}_{2}-,-\mathrm{OH}\right), \quad 6-((E)-4-(\beta-((4-n i t r o)$ phenyl $)$ vinyl $)$ phenyl $)-$ $2.50\left(\mathrm{t}, 2 \mathrm{H}, \mathrm{CH}_{2}-\mathrm{C} \equiv\right), 3.85\left(\mathrm{~m}, 4 \mathrm{H},-\mathrm{CH}_{2} \mathrm{O}-\right.$ hexa-1,3-diyne-1-ol $(\mathbf{1 2 b})$. To a solution con$\mathrm{Ar},-\mathrm{CH}_{2}-\mathrm{O}$ ), $6.50-7.50\left(\mathrm{~m}, 10 \mathrm{H}, 8 \mathrm{H}\right.$ ar., taining $N, N^{\prime}$-dimethylformamide (DMF) (50 

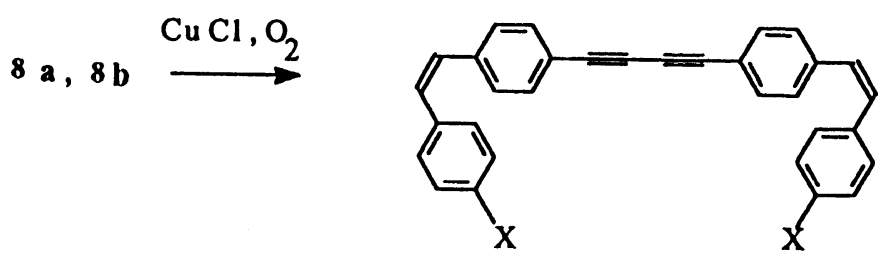

$$
\begin{aligned}
& 11 \text { a } \mathrm{X}=\mathrm{OBu} \\
& 11 \text { b } \mathrm{X}=\mathrm{NO}_{2}
\end{aligned}
$$
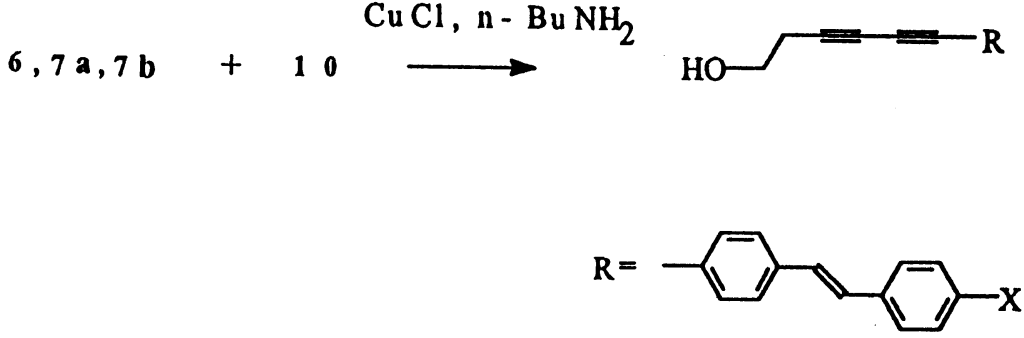

$$
\begin{aligned}
& 12 \text { a } \mathrm{X}=\mathrm{OBu} \\
& 12 \text { b } \mathrm{X}=\mathrm{NO}_{2}
\end{aligned}
$$

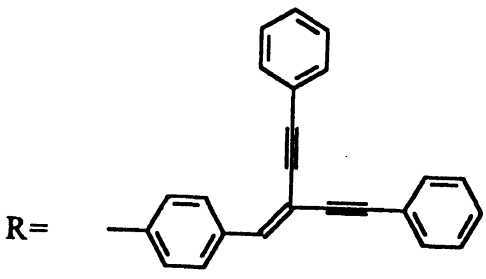

13

Scheme 1.

$\mathrm{ml}), 7 \mathrm{~b}(5 \mathrm{mmol}), \mathrm{CuCl}(0.01 \mathrm{~g}), n$-butylamine $(2 \mathrm{ml})$, water $(2 \mathrm{ml})$, and $0.5 \mathrm{~g}$ of $\mathrm{NH}_{2} \mathrm{OH} \cdot \mathrm{HCl}$, $100 \mathrm{ml}$ of ethanol solution of $11(7 \mathrm{mmol})$ were added dropwise over 2 hours with stirring. The solvents were evaporated under vacuum and the residue was chromatographed on $\mathrm{SiO}_{2}$ with benzene to give compound $\mathbf{1 2 b}$ in $34 \%$ yield. $T_{\mathrm{m}}=204^{\circ} \mathrm{C} \mathrm{FT}-\mathrm{IR}\left(\mathrm{cm}^{-1}\right) 3450(-\mathrm{OH}), 3100$ 3000 (C-H ar.), 2950-2850 (C-H $\left.{ }_{\mathrm{al}}\right), 2240$, $2150(\mathrm{C} \equiv \mathrm{C}-\mathrm{C} \equiv \mathrm{C}), 1589$ ( $\mathrm{C}=\mathrm{C}$ ar.), 1508, $1340\left(-\mathrm{NO}_{2}\right), 955($ trans $-\mathrm{CH}=\mathrm{CH}-) .{ }^{1} \mathrm{H} \mathrm{NMR}$ in $\mathrm{CDCl}_{3}(\delta): 1.54(\mathrm{~s}, 1 \mathrm{H},-\mathrm{OH}), 2.50(\mathrm{t}, 2 \mathrm{H}$, $\left.\mathrm{CH}_{2}-\mathrm{C} \equiv\right), 3.85\left(\mathrm{t}, 2 \mathrm{H},-\mathrm{CH}_{2}-\mathrm{O}\right), 7.20$ (s, $2 \mathrm{H}$ trans $-\mathrm{CH}=\mathrm{CH}-), 7.50-7.80(\mathrm{~m}, 6 \mathrm{H}$ ar. $)$, $8.15-8.35$ ( $\mathrm{d}, 2 \mathrm{H}$ ar.).

6-(4-( $\beta, \beta-($ diethynylphenyl $)$ vinyl $)$ phenyl $)$ hexa-1,3-diyne-1-ol (13). To a solution consisting of tetrahydrofuran (THF) $(50 \mathrm{ml}), 6$ (5 mmol), $\mathrm{CuCl}(0.01 \mathrm{~g}), n$-butylamine $(2 \mathrm{ml})$, water $(2 \mathrm{ml})$, and $0.5 \mathrm{~g}$ of $\mathrm{NH}_{2} \mathrm{OH} \cdot \mathrm{HCl}$, a solution of $11(7 \mathrm{mmol})$ in $100 \mathrm{ml}$ of ethanol was added dropwise over 2 hours with stirring. 
Table I. Elemental analysis data of the monomers and the polymers

\begin{tabular}{|c|c|c|c|c|c|c|c|}
\hline \multirow{2}{*}{ Compound } & \multirow{2}{*}{ Formula } & \multicolumn{3}{|c|}{ Calculated in \% } & \multicolumn{3}{|c|}{ Found in $\%$} \\
\hline & & $\mathrm{C}$ & $\mathbf{H}$ & $\mathrm{N}$ & $\mathrm{C}$ & $\mathrm{H}$ & $\mathbf{N}$ \\
\hline $11 \mathbf{a}$ & $\mathrm{C}_{40} \mathrm{H}_{38} \mathrm{O}_{2}$ & 87.23 & 6.95 & - & 86.89 & 6.95 & - \\
\hline 11b & $\mathrm{C}_{32} \mathrm{H}_{20} \mathrm{~N}_{2} \mathrm{O}_{4}$ & 77.4 & 4.06 & 5.64 & 76.83 & 4.05 & 5.51 \\
\hline $12 \mathbf{a}$ & $\mathrm{C}_{24} \mathrm{H}_{24} \mathrm{O}_{2}$ & 83.87 & 7.02 & - & 84.00 & 7.20 & - \\
\hline $12 b$ & $\mathrm{C}_{20} \mathrm{H}_{15} \mathrm{NO}_{3}$ & 75.70 & 4.76 & 4.41 & 76.04 & 5.01 & 4.43 \\
\hline 13 & $\mathrm{C}_{30} \mathrm{H}_{20} \mathrm{O}$ & 90.88 & 5.08 & - & 89.31 & 5.09 & - \\
\hline Poly-11a & $\left(\mathrm{C}_{40} \mathrm{H}_{38} \mathrm{O}_{2}\right)_{n}$ & 87.23 & 6.95 & - & 86.81 & 6.94 & - \\
\hline Poly-11b & $\left(\mathrm{C}_{32} \mathrm{H}_{20} \mathrm{~N}_{2} \mathrm{O}_{4}\right)_{n}$ & 77.4 & 4.06 & 12.89 & 77.11 & 4.03 & 5.49 \\
\hline Poly-12a & $\left(\mathrm{C}_{24} \mathrm{H}_{24} \mathrm{O}_{2}\right)_{n}$ & 83.87 & 7.02 & - & 83.99 & 7.17 & - \\
\hline Poly-12b & $\left(\mathrm{C}_{20} \mathrm{H}_{15} \mathrm{NO}_{3}\right)_{n}$ & 75.70 & 4.76 & 4.41 & 76.11 & 4.89 & 4.41 \\
\hline Poly-13 & $\left(\mathrm{C}_{30} \mathrm{H}_{20} \mathrm{O}\right)_{n}$ & 90.88 & 5.08 & - & 88.79 & 5.09 & - \\
\hline
\end{tabular}

The solvents were evaporated under vacuum and the residue was chromatographed on $\mathrm{SiO}_{2}$ with benzene to give compound 12a in $44 \%$ yield. $T_{\mathrm{m}}=96^{\circ} \mathrm{C}$. FT-IR $\left(\mathrm{cm}^{-1}\right): 3330(-\mathrm{OH})$, $3100-3000$ (C-H ar.), 2950-2850 (C-H $\left.\mathrm{H}_{\mathrm{a}}\right)$, $2250,2150(\mathrm{C} \equiv \mathrm{C}-\mathrm{C} \equiv \mathrm{C}) 2200(-\mathrm{C} \equiv \mathrm{C}-), 1600$ $\left(\mathrm{C}=\mathrm{C}\right.$ ar.). ${ }^{1} \mathrm{H}$ NMR in $\mathrm{CDCl}_{3}(\delta): 1.35$ (s, 1H, - OH), $2.60\left(\mathrm{t}, 2 \mathrm{H},-\mathrm{CH}_{2}-\mathrm{C} \equiv\right), 3.85$ (t, 2H, $\left.-\mathrm{CH}_{2}-\mathrm{O}\right), 7.12(\mathrm{~s}, 1 \mathrm{H},(-\mathrm{CH}=\mathrm{C}(\mathrm{C} \equiv$ $\left.\mathrm{CPh})_{2}\right), 7.16-7.70$ (m, $10 \mathrm{H}$ ar. $), 7.85-8.15$ (d, $4 \mathrm{H}$, ar.).

The DAs 11a, b, 12a, b, and 13 were polymerized by heating at $225^{\circ} \mathrm{C}$ for $60 \mathrm{~min}$ under a nitrogen atmosphere between glass or quartz slides on the hot plate. DSC and TGA were performed at a heating rate of $20^{\circ} \mathrm{C} \mathrm{min}-1$, under nitrogen with a Dupont 2100 . IR-spectra were taken using a Nikolet $510 \mathrm{p}$ FT-IR spectrometer. ${ }^{1} \mathrm{H}$ NMR spectra were taken in $\mathrm{CDCl}_{3}$ solution using a JEOL PMX60SI spectrometer. UV-spectra were taken using a UV260 Shimadzu instrument either in methanol (monomers) or in the films sandwiched between quartz slides. Elemental analysis of the monomers and the polymers is presented in Table I.

\section{RESULTS AND DISCUSSION}

The DAs 11a, 11b, 12a, 12b, and 13 were solids with colour varying from light yellow (12a) to orange $(\mathbf{1 2 b}, \mathbf{1 1 b})$. The UV-visible absorption spectra of the monomers are shown in Figure 1. All had a long wave absorption maximum in the region from 346 to $364 \mathrm{~nm}$, suggesting that they are highly conjugated. None of the DA monomers synthesized underwent topochemical polymerization on heating or irradiation in the solid state. However, they readily polymerized when heated above the melting point. Figure 2 represents the DSC curves of the monomers $11 \mathbf{a}, 11 \mathbf{b}, 12 \mathrm{a}, 12 \mathbf{b}$, and 13. As can be seen from Figure 2 an exothermic reaction started at a temperature above $200^{\circ} \mathrm{C}$ in all the cases.

The samples of DAs solidified when heated above the melting point (at $225^{\circ} \mathrm{C}$ ) under a nitrogen atmosphere. It took from $2-3 \mathrm{~min}$ for DA 13 to $60 \mathrm{~min}$ for DA 11 a to solidify on heating to give insolible glassy polymers. No significant weight loss was observed by TGA at this temperature, which suggests that the exothermic peaks are due to polymerization of the DA-groups rather than thermal decomposition. The nature of the polymers formed was studied by FT-IR spectroscopy. In all cases, heating of the monomers for 1 hour at $225^{\circ} \mathrm{C}$ under nitrogen did not affect the stretching of the groups except for the diacetylenic ones, which confirms that no decomposition takes place during the polymerization. Figure 3 shows the FT-IR spectra of the diacetylene 


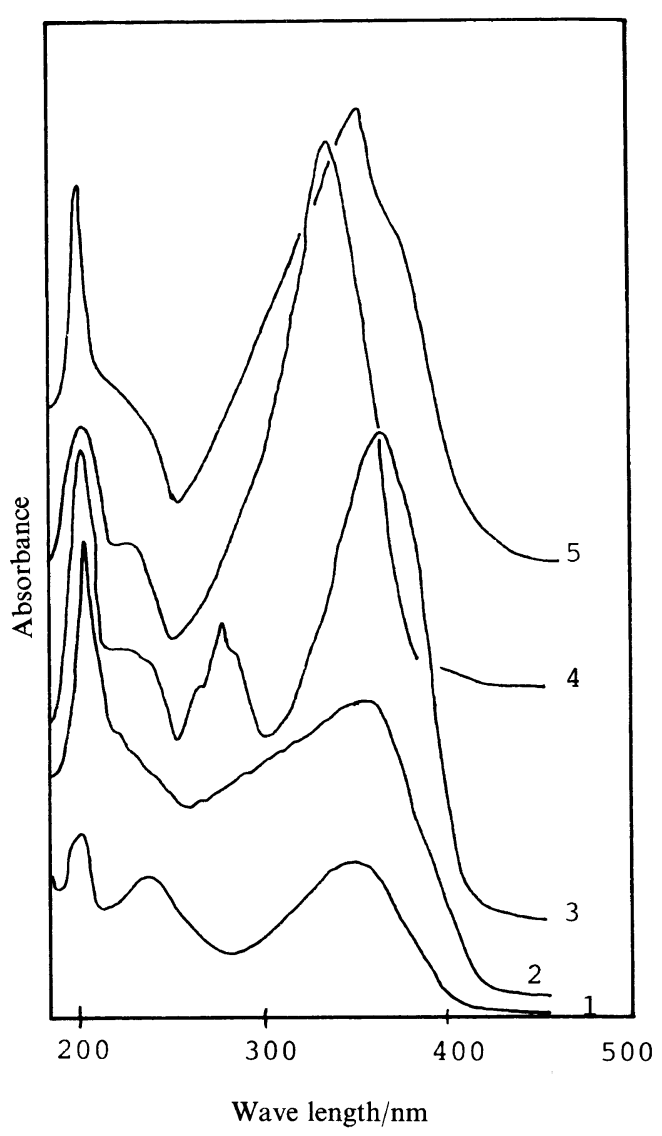

Figure 1. UV-spectra of the monomers: 1 (11a), 2 (11b), 3 (13), 4 (12a), 5 (12b).

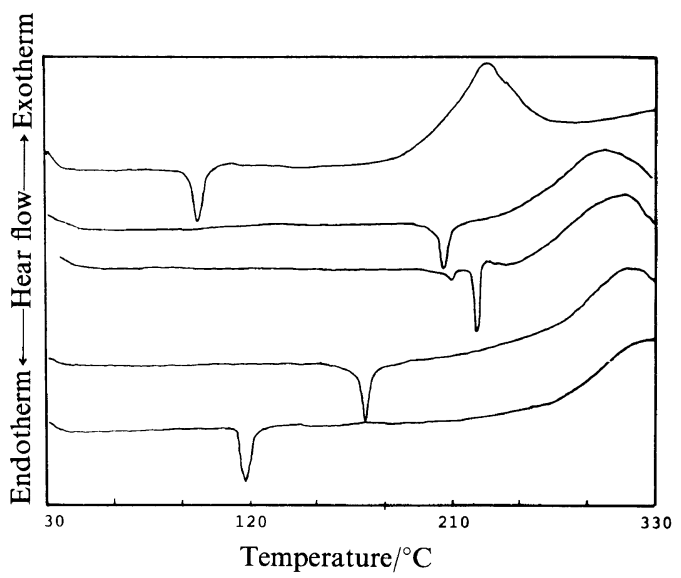

Figure 2. DSC curves of the monomers 1 (11a), 2 (11b), 3 (12a), 4 (12b), 5 (13). region of the monomers and the corresponding polymers. The absorption bands at 2240 and $2150 \mathrm{~cm}^{-1}$ in $12 \mathbf{a}$ and $12 \mathbf{b}$, corresponding to the stretching of the diacetylene group completely disappeared in poly-12a, and poly-12b and a new band appeared at $2195 \mathrm{~cm}^{-1}$, which corresponded to the stretching of a conjugated triple bond of a polydiacetylene chain. This means that compounds $\mathbf{1 2 a}$ and $\mathbf{1 2 b}$ polymerize in the molten state to form PDA (Scheme 2).

A recent work has shown that the 1,4-polymerization of diacetylene does not always occur exclusively within crystalline organization. ${ }^{12-14}$

Monomers 12a and 12b showed a mesophase with conic structures when heated above the melting points, indicative of nematic melt formation. The liquid crystalline state of the monomers was destroyed by thermal polymerization for $20 \mathrm{~min}$, resulting in amorphous polymers.

Changes similar to those of $12 \mathrm{a}$ and $\mathbf{1 2 b}$ were observed in the FT-IR spectra of 11a and 11b and of 13 on polymerization in the molten state. In the cases of 11a and 11b the band corresponding to the stretching of the conjugated triple bond of the PDA chain overlaps with that of the DA group, which makes it more difficult to distinguish the appearance of a new band. DA 13 has two types of triple bonds: the triple bonds of the DA group and those of the $\beta, \beta$-(diethynylphenyl)styryl groups. The former has two absorption bands in the regions of 2250 and $2150 \mathrm{~cm}^{-1}$. The latter absorbs at $2200 \mathrm{~cm}^{-1}$. The polymerization of DA 13 in the molten state leads to the disappearance of the absorbance at 2250 and $2150 \mathrm{~cm}^{-1}$ but the band at $2200 \mathrm{~cm}^{-1}$ remains unchanged. In this case the stretching of the triple bond of PDA chain, which should have appeared after the molten state polymerization of DA 13, matches with the absorption of the triple bonds of $\beta, \beta$-(diethynylphenyl)styryl groups 13 and can not be seen as a separate band.

It is rather difficult to distinguish clearly between 1,4- and 1,2-addition structures, es- 
L. FoMina et al.
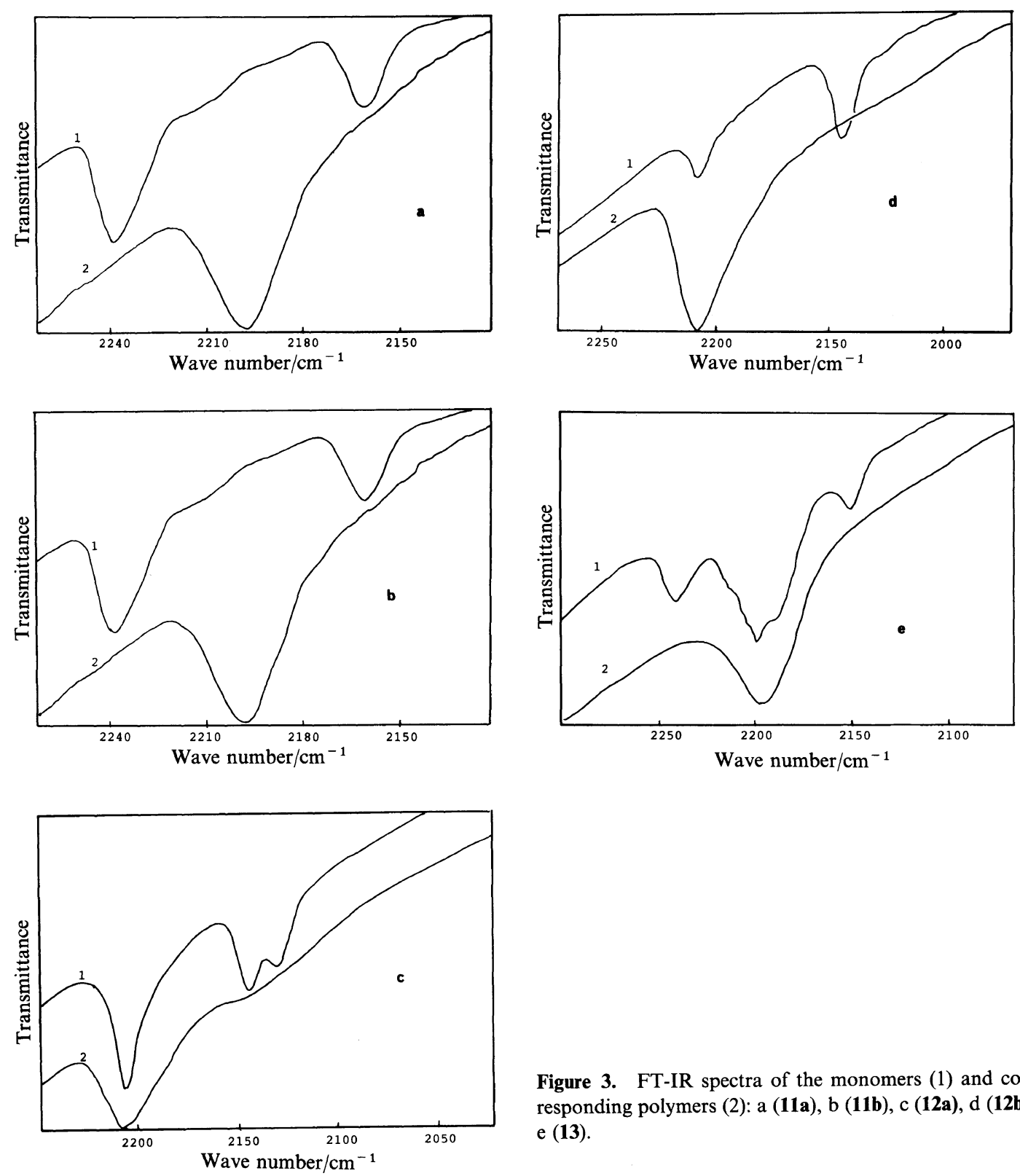

Figure 3. FT-IR spectra of the monomers (1) and corresponding polymers (2): a (11a), b (11b), c (12a), d (12b), e (13).

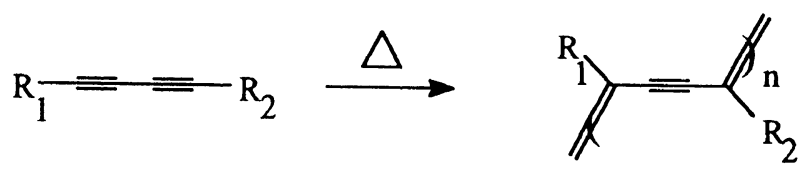

Scheme 2. 
pecially when the polymers are insoluble. The CP MAS ${ }^{13} \mathrm{C}$ spectroscopy which so far is the best tool to study a structure of insoluble polymers, gives little information on the carbons of PDA chain because their signals are hardly to be resolved, probably due to a large dispersion of chemical shifts observed for conjugated carbons of varying length. ${ }^{15}$

However, FTIR data provided us a circumstantial evidences of 1,4-addition. First, the position of the new peak of triple bond stretching at $2200 \mathrm{~cm}^{-1}$ arising after thermal polymerization matches with that of topochemically polymerized PDA. ${ }^{14}$ Secondly, the intensity of this peak is equal to or lower than that of the diacetylene stretching, whereas in the case of 1,2-addition unsymmetrically substituted triple bond is formed and it should give more intense peak. Thirdly, if 1,2-addition had taken place then the remaining triple bonds should have been consumed completely on prolonged heating because of their 3,4-polymerization. However, this is not observed in the case of this work and the absorption bond at $2200 \mathrm{~cm}^{-1}$ does not decreases its intensity after increasing of the polymerization time over 4 hours. This fact counts in favor of 1,4 addition structure, because PDA triple bonds are thermally quite stable.

The polymers prepared by the molten state polymerization of DA were amorphous in nature, as observed with a polarizing microscope, and they gave films of excellent transparency with colours from red to purple when the polymerization was performed between glass or quartz slides. The visible absorption spectra of these samples are shown in Figure 4. As can be seen, all the polymers have a maximum in the region of $500-550 \mathrm{~nm}$, characteristic of a conjugated polymer chain.

Many PDAs obtained by the molten state polymerization do not show absorption maxima in the visible region, but instead exhibit a sliding curve from the shorter wave length region down to the longer. Topochemically polymerized PDAs generally show sharp max-

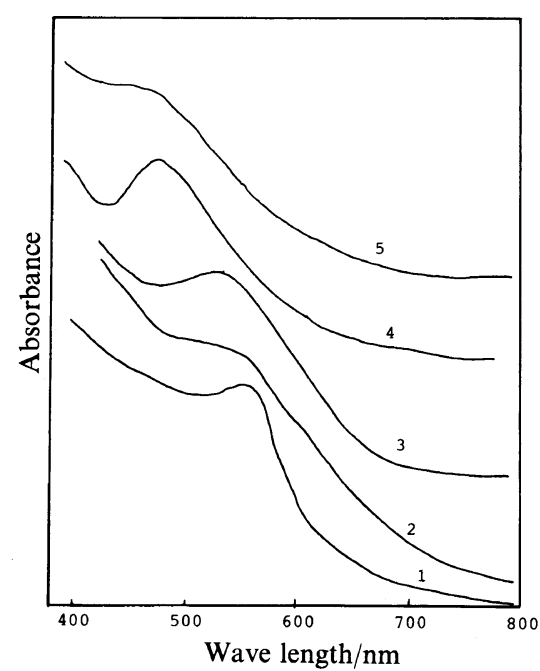

Figure 4. Visible absorption spectra of the polymers. 1 (Poly-11a), 2 (Poly-11b), 3 (Poly-13), 4 (Poly-12a), 5 (Poly12b).

ima in the visible region. Considering from the IR spectra, elemental analysis and rapid polymerization, the DAs polymerized in this work appear to form PDAs of mainly 1,4structure, as in the case of topochemical polymerization.

Acknowledgments. This work was supported by the Grant No. 054-E of CONACyT (Consejo Nacional de Ciensias y Tecnologia). Thanks are also due to Carmen Vazquez and M. Angel Canseco for assistance in the thermal analysis and UV-spectroscopy measurements, respectively.

\section{REFERENCES}

1. G. Wegner, Naturforsch., 24B, 824 (1969).

2. H.-J. Cantow, Ed., "Advances in Polymer Science," Series 63: Springer Verlag, Berlin 1984; D. Bloor and R. R. Chance, Ed., "Polydiacetylenes," NATO ASI Series, E, Applied Science N 102, Martinus Nijihoff, Dordrecht, 1985.

3. D. C. Chemila "Nonlinear Optical Properties of Organic Molecules and Crystals," Vol. 2, J. Zyss, Ed., Academic Press, Inc., New York, N. Y., 1987.

4. J. L. Bredas and R. Silbey, Ed., "Conjugated Polymers," Kluwer Academic Publiches, Dorderecht, 
1991, pp 509-554.

5. R. Baughmann and E. Turi, J. Polym. Sci., Polym. Phys. Ed., 11, 2453 (1973).

6. T. Ogawa and S. Fomine, Trends in Polymer Science, 2, 308 (1994).

7. L. Alexandrova, C. Chavalin, and T. Ogawa, "Proceeding of POLYMEX-93, (International Symposium on Polymers, Nov. 1-5. 1993, Cancun, Mexico)". IIM-UNAM, Mexico DF. 1993, p 215.

8. G. Burillo, P. Carreon, T. Ogawa, M. Solelo, and R. E. Navarro, Polym. Commun., 32, 248 (1991).

9. P. Carreon, G. Burillo, M. A. Lopez, and T. Ogawa, "Proceeding (Libro de Resumenes)", Simposio Iberoamericano de Polímeros, Vigo, Spain, 28 June-3 July, 1992. The Grupo Español de Polímeros,
Madrid, Spain, 1992, p 333.

10. P. Carreon, G. Burillo, and T. Ogawa, "Proceeding of POLYMEX-93, (International Symposium on Polymers Nov. 1-5, 1993, Cancun, Mexico)”. IIM-UNAM, Mexico DF. 1993, p 133.

11. W. B. Austin, N. Bilow, W. J. Kelleghan, and K. S. Y. Lau, J. Org. Chem., 46, 2280 (1981).

12. M. A. Schen, K. Kotowski, and J. Cline, Polymer, 32, 1821 (1991).

13. S. Fomin, R. Neyra, and T. Ogawa, Polym. J., 26, 845 (1994).

14. S. Fomin, M. Marin, and T. Ogawa, Macromol. Symp., 84, 94 (1994).

15. H. W. Beckham and M. F. Rabner, Macromolecules, 22, 2130 (1989). 